\title{
ANALISIS TINGKAT PENDAPATAN ANTARA USAHATANI JAGUNG PANEN MUDA DAN PANEN PIPILAN DI KABUPATEN SERANG PROVINSI BANTEN
}

\author{
Oleh \\ DIAN ANGGRAENI \\ Fakultas Pertanian Universitas Sultan Ageng Tirtayasa \\ e-mail: dian.1452@yahoo.co.id
}

\begin{abstract}
Abstrak
Jagung (Zea mays) merupakan salah satu komoditas strategis dalam perekonomian Indonesia, karena merupakan bahan makanan penghasil karbohidrat kedua setelah padi. Penelitian ini bertujuan untuk (1) mengetahui besarnya biaya antara usahatani jagung panen muda dengan panen pipilan (2). Mengetahui pendapatan usahatani jagung panen muda dan panen pipilan, (3) mengetahui kelayakan usahatani jagung di Kabupaten Serang Provinsi Banten. Metode yang digunakan dalam penelitian ini adalah survey. Metode penentuan sampel dengan cara multistage random sampling dengan total sampel sebanyak 101 petani jagung. Data dianalisis dengan cara tabulasi dan menggunakan rumus biaya, pendapatan usahatani dan R/C ratio. Hasil penelitian menunjukan bahwa: 1) Rata-rata besarnya biaya usahatani jagung panen muda per hektar per musim tanam Rp 5.343.950,00 sedangkan biaya usahatani jagung panen pipilan sebesar Rp 5.762.211,00 per hektar per musim tanam; 2) Rata-rata besarnya pendapatan usahatani jagung panen muda sebesar Rp. 10.217.411,00 per hektar per musim tanam. Sedangkan pendapatan dari usahatani jagung panen pipilan sebesar Rp 10.668.564,00 per hektar per musim tanam; 3) R-C ratio untuk usahatani jagung panen muda 2,91 sedangkan besarnya $\mathrm{R} / \mathrm{C}$ untuk usahatani jagung panen pipilan 2,85. Dengan demikian, usahatani jagung baik yang menggunakan sistim panen muda atau panen pipilan di Kabupaten Serang layak untuk dikembangkan.
\end{abstract}

Kata kunci: usahatani, jagung, biaya, pendapatan, R/C

\section{PENDAHULUAN}

Permintaan akan bahan pangan di Indonesia dari tahun ke tahun semakin meningkat terutama bahan pangan uatama seperti padi, jagung, dan kedelai. Jagung adalah salah satu bahan pangan terpenting karena merupakan sumber karbohidrat kedua setelah padi. Selain sebagai bahan pangan, jagung juga merupakan komoditas tanaman pangan setelah padi. Disamping itu komoditas ini dapat digunakan sebagai pakan ternak dan bahan baku industri seperti industri etanol (Purwono dan Hartono, 2005).

Hal yang sama diungkapkan oleh Kasryno(2006) bahwa jagung dapat dimanfaatkan untuk pangan, pakan dan bahan baku indutri. Jagung menjadi salah satu komoditas pertanian yang sangat penting dan saling terkait dengan industri besar. Selain untuk konsumsi, untuk sayuran, buah jagung bisa diolah menjadi aneka makanan. Selain itu pipilan keringnya dimanfaatkan untuk pakan ternak.

Kabupaten Serang adalah salah satu daerah di Provinsi Banten yang cocok untuk budidaya komoditas jagung. Meningkatnya permintaan untuk komoditas jagung pipilan tidak diikuti oleh meningkatnya petani yang melakukan usahatani jagung tersebut, hal ini disebabkan oleh adanya beberapa faktor sosial dan ekonomi. Salah satu faktor ekonomi adalah pendapatan yang diperoleh dari usahatani jagung tersebut. Untuk meningkatkan pendapatan petani, maka diperlukan kemampuan dalam pemilihan dan pengalokasian faktor produksi tersebut secara efektif dan efisien.

Berdasarkan latar belakang di atas, maka sangat penting dilakukan kajian berkaitan dengan analisis tingkat pendapatan antara usahatani jagung muda dengan jagung pipilan. Penelitian ini dilaksanakan untuk mengetahui :

1. Besarnya biaya antara usahatani jagung panen muda dengan panen pipilan

2. Besarnya pendapatan antara usahatani jagung panen muda dengan panen pipilan

3. Tingkat kelayakan usahatani jagung di Kabupaten Serang.

\section{TINJAUAN PUSTAKA}

Usahatani adalah salah satu ilmu yang mempelajari bagaimana seseorang mengalokasikan sumberdaya yang ada secara efektif dan efisien untuk memperoleh keuntungan yang sangat tinggi pada waktu tertentu. Suatu usahatani dikatakan efektif jika 


\section{AIMBAR \\ Agribisnis}

ISSN 2460-4321

Volume 1・ Nomor 2・ Januari 2016

petani dapat mengalokasikan sumberdaya yang mereka miliki secara baik, sedangkan dikatakan efisien jika pemanfaatan sumberdaya dapat menghasilkan keluaran yang melebihi masukan (Soekartawi,2005)

Menurut Suratiyah (2006), usahatani adalah suatu kegiatan mengusahakan dan mengkoordinasikan faktor-faktor produksi berupa lahan, tenaga kerja, dan modal sehingga memberikan manfaat sebaik-baiknya. Usahatani merupakan cara-cara petani menetukan, mengorganisasikan, dan mengkoordinasikan penggunaan faktor-faktor produksi seefektif dan seefisien mungkin sehingga usaha tersebut memberikan pendapatan semaksimal mungkin.

Dengan demikian dalam usahatani memerlukan biaya yang merupakan pengeluaran produsen untuk memperoleh faktor produksi dan bahan penunjang lainnya, agar produk yang telah direncanakan dapat terwujud (Kartasaputra,1998).

Biaya adalah nilai dari seluruh penggunaan sarana produksi (input) dan lain-lain yang diperlukan atau dibebankan pada proses produksi yang bersangkutan (Soekartawi,2005). Sementara Rahim dan Hastuti (2007), menyatakan bahwa biaya terbagai dalam 2 bagiantaranya biaya tetap dan biaya variabel. Biaya tetap adalah biaya yang dikeluarkan untuk mendapatkan faktor produksi atau input yang tidak dapat diubah jumlahnya dalam jangka pendek dan besarnya biaya tetap tidak tergantung kepada jumlah produk yang dihasilkan. Beberapa komponen yang termasuk kedalam biaya tetap diantaranya, pajak bumi dan bangunan, penyusutan peralatan yang dipergunakan dalam usahatai tersebut, dan bunga modal dari modal yang dpergunakan. Biaya variabel adalah biaya yang dipergunakan untuk membeli faktor produksi yang dipergunakan.

Menurut Soekartawi (2005), menyatakan bahwa penerimaan adalah sesuatu yang dihasilkan dari adanya suatu tindakan ekonomi berupa penjualan produk. Penerimaan dapat diketahui dengan mengalikan jumlah produksi total dengan harga produk tersebut (Rahim dan Hastuti,2007).

Salah satu indikator suatu usahatani layak untuk dikembangkan adalah dengan melihat nilai $\mathrm{R} / \mathrm{C}$ ratio dari usahatani tersebut. Sesuai yang diungkapkan Soekartawi (2002) bahwa untuk mengetahui tingkat kelayakan suatu cabang usaha salah satunya dapat dilihat dengan analisis imbangan antara penerimaan dengan biaya produksi atau revenue cost ratio $(\mathrm{R} / \mathrm{C})$. Apabila R/C lebih besar dari satu, maka usahatani tersebut menguntungkan dan layak untuk dikembangkan. Apabila R/C sama dengan satu, maka usahatani tersebut tidak memperoleh keuntungan dan tidak menderita kerugian (impas). Apabila R/C lebih kecil dari satu, maka usahatani tersebut dianggap merugi dan tidak layak untuk dikembangkan.

\section{METODE PENELITIAN}

Penelitian dilakukan di Kabupaten Serang Provinsi Banten, dengan waktu penelitian pada Musim Tanam kedua bulan Agustus 2013.

Data yang diperoleh merupakan data primer dan data sekunder. Data primer diperoleh dengan teknik wawancara terhadap petani jagung dengan bantuan kuesioner yang sudah disiapkan. Data sekunder diperoleh dengan cara study literatur dan menelaah hasil penelitian terdahulu, laporan dari instansi terkait, maupun publikasi lain yang relevan.

Sampel ditentukan dengan cara multistage cluster random sampling, dengan tiga tahapan. Tahap petama menentukan kecamatan sebagai sentra komoditas jagung. Tahap kedua memilih desa yang dijadikan sebagai Secondary Sampling Unit (SSU), dan tahap ketiga memilih petani sebagai sampel, dalam penelitian ini menggunakan simple random sampling.

1. Mengetahui besarnya biaya dalam usahatani jagung digunakan rumus sebagai berikut

$\mathrm{TC}=\mathrm{TFC}+\mathrm{TVC}$

Dimana :

$\mathrm{TC}=$ Total Cost ( biaya total usahatani)

$\mathrm{TFC}=$ Total Fixed Cost (biaya tetap total)

$\mathrm{TVC}=$ Total Variable Cost ( biaya variabel total )

2. Mengetahui besarnya pendapatan usahatani jagung menggunakan formulasi sebagai berikut :

$\pi=\mathrm{TR}-\mathrm{TC}$

Dimana :

$\pi=$ Pendapatan usahatani jagung 


\section{Analisis Tingkat Pendapatan Antara Usahatani Jagung Panen Muda dan Panen Pipilan di Kabupaten Serang Provinsi Banten DIAN ANGGRAENI}

$\mathrm{TR}=$ Total Revenue (penerimaan total), merupakan perkalian antara output dengan harga output

$\mathrm{TC}=$ Total Cost (biaya total ) usahatani jagung

3. Mengetahui kelayakan usahatani jagung dengan menggunakan $\mathrm{R} / \mathrm{C}$, yang dihitung dengan rumus sebagai berikut :

$\mathrm{R} / \mathrm{C}=\mathrm{TR} / \mathrm{TC}$

Dimana

$\mathrm{R} / \mathrm{C}=$ Ratio

$\mathrm{TR}=$ Total Revenue (penerimaan total)

$\mathrm{TC}=$ Total Cost $($ biaya total)

Dengan ketentuan :

a. $\mathrm{R} / \mathrm{C}>1$, maka usahatani jagung menguntungkan dan layak untuk dikembangkan

b. $\mathrm{R} / \mathrm{C}=1$, maka usahatani jagung berada pada kondisi tidak untung dan tidak rugi

c. $\mathrm{R} / \mathrm{C}<1$, maka usahatani jagung tidak menguntungkan dan tidak layak untuk dikembangkan.

\section{HASIL DAN PEMBAHASAN}

Biaya produksi usahatani dalam penelitian ini adalah semua biaya yang dikeluarkan dalam proses produksi usahatani jagung. Analisis biaya produksi sebenarnya diperlukan untuk menentukan harga jual komoditi yang dihasilkan dari usaha tersebut, tetapi sebenarnya petani tidak memiliki catatan yang lengkap, sehingga dalam proses menjual hasil produksinya hanya berpedoman pada harga yang berlaku di pasar, di satu sisi petani sebenarnya hanya sebagai penerima harga (price taker).

Harga jual produk merupakan faktor penentu dan motivator utama bagi petani untuk berproduksi sebesar-besarnya (Mosher, 1989), namun demikian harga merupakan salah satu faktor yang sulit dikendalikan, khususnya pada komoditas pertanian, pada saat panen raya cenderung harga turun, sementara pada saat paceklik harga langsung melonjak. Berkaitan faktor harga tersebut pada umumnya petani berada pada posisi penerima harga (price taker).

Biaya produksi rata-rata per hektar untuk usahatani jagung dengan sistem panen muda berbeda dengan sistem panen tua (pipilan). Perbedaan yang nampak pada biaya variabel karena pada waktu panen tua/pipilan terdapat penanganan pasca panen (pemipilan dan penjemuran), sehingga terdapat penambahan tenaga kerja yang berdampak terhadap meningkatnya biaya tenaga kerja khususnya. Proses penanganan pasca panen pada jagung pipilan merupakan salah satu upaya petani dalam menyiasati harga. Proses pengolahan yang optimal, menyebabkan jagung pipilan dapat disimpan lama, dengan demikian petani dapat menjualnya pada saat harga tinggi. Perbedaan lain dari aspek penggunaan pupuk baik itu urea, TSP atau pun pupuk kandang, usahatani jagung pipilan lebih tinggi. Aspek penggunaan benih juga untuk usahatani jagung waktu panen pipilan memerlukan biaya yang lebih tinggi walaupun perbedaanya tidak terlalu besar.

Secara umum tingginya biaya usahatani merupakan suatu kendala bagi petani kecil, karena akses terhadap sumber modal sulit mereka peroleh. Besar kecilnya biaya yang dikeluarkan menentukan besarnya pendapatan yang akan diterima petani. Berkaitan dengan biaya usahatani jagung secara lebih jelas dapat dilihat pada Tabel 1 .

Tabel 1. Rincian Biaya Tetap dan Biaya Variabel Per Hektar Usahatani Jagung di Kabupaten Serang

\begin{tabular}{llrrc}
\hline \multirow{2}{*}{ No. Biaya } & & \multicolumn{3}{c}{ Waktu Panen } \\
\cline { 3 - 5 } & & $\begin{array}{c}\text { Muda } \\
(\mathbf{R p})\end{array}$ & $\begin{array}{c}\text { Pipilan } \\
(\mathbf{R p})\end{array}$ & $\begin{array}{c}\text { Perbedaan } \\
(\mathbf{\%})\end{array}$ \\
\hline 1. & & Jenis Sarana Produksi & \\
& a. Benih & $840.180,00$ & $848.000,00$ & 0,92 \\
& b. Pupuk kandang dan buatan & $1.366 .246,00$ & $1.603 .000,00$ & 14,76 \\
& c. Pestisida & $145.574,00$ & $100.500,00$ & 30,96 \\
2. & Tenaga kerja & $2.827 .608,00$ & $2.999 .250,00$ & 5,72 \\
3. & Biaya tetap & $164.342,00$ & $211.461,00$ & 22,28 \\
\hline \multicolumn{2}{c}{ Jumlah } & $5.343 .950,00$ & $5.762 .211,00$ & 7,25 \\
\hline
\end{tabular}




\section{AIMBAR \\ Agribisnis \\ ISSN 2460-4321}

Volume 1・ Nomor 2・ Januari 2016

Berdasarkan Tabel 1. dapat diketahui bahwa perbedaan biaya yang sangat mencolok adalah biaya sarana produksi yaitu $47,68 \%$ spesifik untuk pembelian pestisida sebesar $30,96 \%$, hal ini disebabkan pada usahatani jagung panen muda pada saat penelitian terjadinya serangan hama yang lebih tinggi dibanding pada usahatani jagung panen pipilan, yang berdampak terhadap meningkatnya penggunaan pestisida pada usahatani tersebut. Pada penggunaan pupuk, baik pupuk kandang atau pupuk buatan, pemakaian benih dan penggunaan tenaga kerja, juga terdapat perbedaan walaupun prosentasenya tidak terlalu tinggi.

Pendapatan yang tinggi merupakan salah satu indikator keberhasilan suatu usahatani. Pada usahatani jagung sistim panen muda dengan panen pipilan terdapat perbedaan pendapatan yang disebabkan oleh perbedaan produksi jagung, harga jagung, serta biaya yang dikeluarkan untuk proses produksi. Rata-rata produksi jagung sistim panen muda per hektar per musim tanam adalah $10.443,87 \mathrm{~kg}$, dengan harga Rp 1490 per kg. Dengan demikian penerimaan yang diperoleh dari usahatani jagung panen muda sebesar Rp. 15.561.361,00 per hektar per musim tanam.

Rata-rata produksi jagung panen pipilan per hektar per musim tanam sebanyak $5921 \mathrm{~kg}$, dengan harga $\mathrm{Rp} 2775$ per $\mathrm{kg}$. Dengan demikian penerimaan yang diperoleh petani dari usahatani panen pipilan senilai $\mathrm{Rp}$. 16.430.775,00 per hektar per musim tanam.

$\mathrm{R} / \mathrm{C}$, merupakan perbandingan antara penerimaan dengan total biaya usahatani. Dari hasil analisis, maka R/C untuk usahatani jagung panen muda adalah 2,91, sedangkan $\mathrm{R} / \mathrm{C}$ untuk usahatani jagung panen pipilan sebesar 2,85. $\mathrm{Ni}$;ai R/C usahatani panen jagung muda lebih besar dari jagung panen pipilan, hal ini mengandung pengertian bahwa usahatani jagung panen muda "relatif lebih efisien" dibanding usahatani panen pipilan. Namun demikian usahatani jagung dengan kedua sistim panen tersebut layak untuk dikembangkan di Kabupaten Serang.

Berkaitan dengan biaya, penerimaan, pendapatan dan R/C dari usahatani jagung di Kabupaten Serang lebih jelasnya dapat dilihat pada Tabel 2.

Tabel 2. Biaya Produksi dan Pendapatan Usahatani Jagung Waktu Panen Muda dan Panen Pipilan Per Hektar Per Musim Tanam

\begin{tabular}{llccrr}
\hline & & & \multicolumn{3}{c}{ Waktu Panen } \\
\cline { 4 - 6 } No & \multicolumn{1}{c}{ Keterangan } & Satuan & \multicolumn{1}{c}{$\begin{array}{c}\text { Muda } \\
(\mathbf{R p})\end{array}$} & \multicolumn{1}{c}{$\begin{array}{c}\text { Pipilan } \\
(\mathbf{R p})\end{array}$} & \multicolumn{1}{c}{$\begin{array}{c}\text { Perbedaan } \\
(\mathbf{R p})\end{array}$} \\
\hline 1. & Biaya Tetap & $\mathrm{Rp}$ & $164.342,00$ & $211.461,00$ & $47.119,00$ \\
2. & Biaya Variabel & $\mathrm{Rp}$ & $5.179 .608,00$ & $5.550 .750,00$ & $371.142,00$ \\
3. & Total Biaya produksi & $\mathrm{Rp}$ & $5.343 .950,00$ & $5.762 .211,00$ & $418.261,00$ \\
4. & Penerimaan Total & $\mathrm{Rp}$ & $15.561 .361,00$ & $16.430 .775,00$ & $869.414,00$ \\
5. & Pendapatan Bersih & $\mathrm{Rp}$ & $10.217 .411,00$ & $10.668 .564,00$ & $451.153,00$ \\
6. & Revenue/Cost & - & 2,91 & 2,85 & - \\
\hline
\end{tabular}

Dari Tabel di atas dapat disimpulkan bahwa usahatani jagung baik dengan sistim panen muda atau panen pipilan menguntungkan dan layak untuk dikembangkan di Kabupaten Serang.

\section{PENUTUP \\ Simpulan}

Berdasarkan hasil dan pembahasan, maka dapat ditarik simpulan sebagai berikut :

1. Rata-rata besarnya biaya usahatani jagung panen muda per hektar per musim tanam Rp 5.343.950,00 sedangkan biaya usahatani jagung panen pipilan sebesar Rp 5.762.211,00 per hektar per musim tanam.
2. Rata-rata besarnya pendapatan usahatani jagung panen muda sebesar Rp. 10.217.411,00 per hektar per musim tanam. Sedangkan pendapatan dari usahatani jagung panen pipilan sebesar Rp 10.668.564,00 per hektar per musim tanam.

3. R-C ratio untuk usahatani jagung panen muda 2,91 sedangkan besarnya $\mathrm{R} / \mathrm{C}$ untuk usahatani jagung panen pipilan 2,85. Dengan demikian, usahatani jagung baik 


\section{Analisis Tingkat Pendapatan Antara Usahatani Jagung Panen Muda dan Panen Pipilan di Kabupaten Serang Provinsi Banten \\ DIAN ANGGRAENI}

yang menggunakan sistim panen muda atau panen pipilan di Kabupaten Serang layak untuk dikembangkan.

\section{Saran}

Berdasarkan simpulan diatas, maka dapat disarankan sebagai berikut :

1. Usahatani jagung di Kabupaten Serang layak untuk dikembangkan

2. Perlu kajian lanjutan berkaitan dengan strategi pengembangan usahatani jagung

\section{DAFTAR PUSTAKA}

Kartasapoetra, A.G. 1998. Ekonomi Pertanian. Jakarta. LP3ES

Kasryno, F. 2006. Suatu Penilaian Mengenai Prospek Masa Depan Jagung di Indonesia, makalah disampaikan pada Seminar dan Lokakarya Nasional Jagung, 29-30 September 2006, Balai Penelitian Tanaman Serealia. Maros.

Mosher. A.T. 1989. Menggerakan dan Membangun Pertanian. Jakarta, Yasaguna.

Purwono dan Hartono.2007. Bertanam Jagung Unggul. Penebar Swadaya. Jakarta

Rahim, A dan Hastuti, D. 2007. Pengantar Teori dan Kasus Ekonomika Pertanian. Penebar Swadaya. Jakarta.

Soekartawi.2005. Analisis Usahatani. PT. Raja Grafindo Persada. Jakarta.

Suratiyah, K. 2006. Ilmu Usahatani. Penebar Swadaya. Jakarta 


\section{AIMBAR Agribisnis}

ISSN 2460-4321

Volume 1・Nomor 2・Januari 2016 